\title{
PENYULUHAN MAKANAN DAN JAJANAN SEHAT DALAM MENINGKATKAN PENGETAHUAN TENTANG GIZI DI SDN KARANGJAYA III KECAMATAN PEDES KARAWANG
}

\author{
${ }^{1}$ Yulistina Nur DS, ${ }^{2}$ Ayu Fitri, ${ }^{3}$ Sinta Maria Dewi \\ PGSD Fakultas Keguruan dan Ilmu Pendidikan \\ Universitas Buana Perjuangan \\ yulistina.nur@ubpkarawang.ac.id \\ ayufitri@ubpkarawang.ac.id \\ sinta.maria@ubpkarawang.ac.id
}

\begin{abstract}
Community service activities are one form of the implementation of Tri Dharma of Higher Educationwhich has the aim that the lecturers and students of the Primary School Teacher Education Study Program have community skills. The target of this service is students in Karangjaya III Elementary School Karangjaya Village, Pedes District, Karawang. This activity was held on 4-6 August 2017. This service activity was packaged in the form of counseling. After being given counseling, they were then guided to identify and distinguish healthy and $\mathrm{s}$

afe food and snacks for elementary schools. From community service activities, results and benefits were obtained including increasing the knowledge of students about healthy and nutritious types of food and snacks.
\end{abstract}

Keyword : Healthy Food and Nutrition Counseling, Nutrition, Elementary Students

\begin{abstract}
Abstrak : Kegiatan pengabdian pada masyarakat adalah salah satu bentuk penyelenggaraan Tri Dharma Perguruan Tinggi yang memiliki tujuan supaya dosen dan mahasiswa Program Studi Pendidikan Guru Sekolah Dasar mempunyai keterampilan bermasyarakat. Sasaran dari pengabdian ini adalah siswa/siswi di SD Negeri Karangjaya III Desa Karangjaya Kecamatan Pedes Karawang. Kegiatan ini dilaksanakan pada tanggal 4-6 Agustus 2017. Kegiatan pengabdian ini dikemas dalam bentuk penyuluhan. Setelah diberi penyuluhan, selanjutnya mereka dibimbing untuk mengidentifikasi dan membedakan makanan dan jajanan sehat dan aman untuk sekolah dasar. Dari kegiatan pengabdian masyarakat, diperoleh hasil dan manfaat diantaranya adalah meningkatnya pengetahuan siswa-siswa tentang jenis makanan dan jajanan sehat dan bergizi.
\end{abstract}

Kata Kunci : Penyuluhan Jajanan dan Makanan sehat, Gizi, Siswa SD 


\section{Pendahuluan}

Makanan jajanan sangat beragam jenisnya dan berkembang pesat di Indonesia. Makanan jajanan dapat memberikan kontribusi zat gizi dalam tubuh yaitu berkisar antara 10-20\%. Energi yang didapat dari makanan jajanan 17,36\%, protein $12,4 \%$, karbohidrat $15,1 \%$ dan lemak $21,1 \%$ terhadap konsumsi sehari (Ulya,2003). Makanan jajanan juga merupakan masalah yang perlu menjadi perhatian masyarakat, karena terdapat beberapa makanan jajanan yang tidak higienis sehingga sangat berisiko terhadap cemaran yang dapat mengganggu kesehatan. Anak sekolah dasar sangat rentan dalam masalah ini karena anak tersebut belum mengerti cara memilih jajanan yang sehat sehingga dapat berakibat buruk pada kesehatannya sendiri (Suci, 2009). Anak sekolah biasanya sering melupakan sarapan pagi dan memilih membeli makanan jajanan di sekolah. Anakanak membeli makanan jajanan menurut kesukaannya tanpa memikirkan bahanbahan yang terkandung di dalamnya (Judarwanto, 2008). Anak-anak merupakan salah satu kelompok yang berisiko tinggi tertular penyakit melalui makanan maupun minuman (Antara, 2004). Anak-anak sering menjadi korban penyakit bawaan makanan akibat konsumsi makanan yang dibeli di kantin sekolah atau penjaja kaki lima (WHO, 2006).

Frekuensi kejadian luar biasa (KLB) keracunan makanan pada anak di sekolah meningkat pada tahun 2004. KLB tertinggi terjadi pada anak sekolah dasar (SD) yaitu 19 kejadian dengan jumlah korban sakit sebanyak 575 orang (Sekretariat Jenderal Jejaring Intelijen Pangan, 2005). Banyak jajanan yang kurang memenuhi syarat kesehatan sehingga justru mengancam kesehatan anak (Khomsan, 2003).

Penelitian Djaja (2003) di 3 (tiga) jenis tempat pengelolaan makanan (TPM) menyimpulkan bahwa pedagang kaki lima berisiko 3,5 kalilipat terhadap terjadinya kontaminasi makanan dibandingkan dengan usaha jasaboga, restoran dan rumah makan. Hasil penelitian tentang sekolah sehat yang dilakukan oleh Pusat Pengembangan Kualitas Jasmani Depdiknas tahun 2007 pada 640 SD di 20 provinsi yang diteliti, sebanyak $40 \%$ belum memiliki kantin. Sementara dari yang telah memiliki kantin (60\%) sebanyak $84.3 \%$ kantinnya belum memenuhi 
syarat kesehatan, sehingga dapat menimbulkan dampak yang tidak baik bagi gizi dan kesehatan anak. Hasil pemantauan BPOM tahun 2011 menunjukkan ada 35.5\% makanan jajanan anak sekolah tidak memenuhi syarat keamanan. Laporan surveilan Direktorat Survei dan Penyuluhan Keamanan Pangan BPOM menunjukkan selama tahun 2004 diseluruh Indonesia telah terjadi kejadian luar biasa (KLB) keracunan makanan sebanyak 164 kejadian di 25 provinsi yang mencakup 7.366 kasus dan 51 diantaranya meninggal dunia.

Rendahnya tingkat keamanan Pangan Jajanan Anak Sekolah (PJAS) masih menjadi permasalahan penting. Data pengawasan PJAS yang dilakukan Badan POMRI cq Direktorat Inspeksi dan Sertifikasi Pangan bersama 26 Balai Besar/Balai POM di seluruh Indonesia pada tahun 2007 menunjukkan bahwa 45\% PJAS tidak memenuhi syarat karena mengandung bahan kimia berbahaya seperti formalin, boraks, rhodamin, mengandung Bahan Tambahan Pangan (BTP), seperti siklamat dan benzoate melebihi batas aman, sert akibat cemaran mikrobiologi. Faktor-faktor yang mempengaruhi jajanan meliputi faktor intern dan faktor ekstern. Faktor intern mencakup pengetahuan khususnya gizi kecerdasan, kepribadian, penagalaman dan faktor emosional.

Faktor ekstern meliputi orang tua, keluarga, lingkungan, pengaruh oranglain, kebudayaan, media massa, lembaga pendidikan dan agama. Pengetahuan merupakan faktor intern yang mempengaruhi pemilihan makanan jajanan. Pengetahuan gizi adalah kepandaian memilih jajanan yang merupakan sumber zat gizi dan kepandaian dalam memilih jajanan yang sehat (Notoatmodjo, 2003). Pendidikan dan pengetahuan merupakan faktor tidak langsung yang dapat mempengaruhi perilaku seseorang. Pengetahuan yang diperoleh seseorang tidak terlepas dari pendidikan. Pengetahuan gizi yang ditunjang dengan pendidikan yang memadai, akan menanamkan kebiasaan dan penggunaan bahan makanan yang baik. Sehingga pengetahuan gizi akan mempengaruhi perilaku (Azwar, 2008).

Jenis makanan jajanan menurut Widyakarya Nasional Pangan dan Gizi (1998) yang dikutip oleh Sitorus (2007) dapat digolongkan menjadi (3) tiga golongan, yaitu: 
1. Makanan jajanan yang berbentuk panganan, misalnya kue-kue kecil, pisang goreng, kue bugis dan sebagainya.

2. Makanan jajanan yang diporsikan (menu utama), seperti pecal, mie bakso, nasi goreng, mie rebus dan sebagaianya.

3. Makanan jajanan yang berbentuk minuman, seperti ice cream, es campur, jus buah dan sebagainya.

Salah satu tujuan makan adalah supaya tubuh kita sehat, namun disisi lain makan juga dapat menjadi salah satu sumber penyakit. Oleh karena itu menurut Anonim (2002) sebaiknya pilihlah makanan jajanan yang sehat, yaitu makanan jajanan yang segar, bersih dan aman dari cemaran bahan kimia dan fisik.

a. Ciri-ciri makanan dan jajanan yang segar

Cara memilih makanan atau jajanan yang segar, untuk makanan yang telah diolah (digoreng, direbus, dikukus) pilihlah makanan baru saja dimasak (masih panas). Jika sudah dingin atau disimpan, maka pilihlah yang tidak berlendir, tidak berbau asam, tidak berjamur dan rasanya masih wajar (normal).

Untuk buah-buahan segar, pilihlah buah yang kulitnya masih segar atau tidak keriput, tidak busuk atau lembek. Untuk makanan kalengan atau makanan dalam botol, pilihlah kemasan yang tidak penyok, bentuknya masih utuh, tutupnya masih disegel atau belum rusak, tidak bocor, tidak kembung, serta tanggal penggunaannya masih berlaku atau belum kadaluarsa (Anonim, 2002).

b. Ciri-ciri makanan dan jajanan yang bersih

Makanan yang sehat selain keadaannya segar juga harus bersih, tidak dihinggapi lalat, tidak dicemari oleh debu dan bahan-bahan pengotor lainnya.

Makanan yang bersih mempunyai ciri-ciri:

1. Bagian luarnya terlihat bersih, tidak terlihat ada kotoran yang menempel.

2. Makanan tersebut disajikan dalam piring atau wadah tempat makanan yang tidak berdebu.

3. Tidak terdapat rambut atau isi stepler.

4. Disajikan dalam keadaan tertutup atau dibungkus dengan plastik, kertas tidak bertinta, daun pisang atau daun lainnya. 
5. Makanan dimasak, disimpan atau disajikan di tempat yang jauh dari tempat pembuangan sampah, got, dan tepi jalan yang banyak dilalui kenderaan.

6. Makanan dimasak dengan peralatan yang bersih dengan menggunakan air bersih, tidak berbau atau keruh (Anonim, 2002).

c. Ciri-ciri makanan dan jajanan yang aman

Makanan yang sehat, selain segar dan bersih juga tidak boleh mengandung bahan kimia yang berbahaya. Bahan-bahan kimia yang biasa ditambahkan kedalam makanan secara sengaja disebut bahan tambahan pangan (zat aditif pangan). Bahan kimia yang biasa ditambahkan ke dalam makanan saat pengolahan yaitu:

1. Bahan pewarna

2. Bahan pemanis

3. Bahan pengawet

4. Bahan pengenyal

5. Bahan penambah rasa

Bahan tambahan makanan umumnya berupa bahan-bahan kimia yang asing bagi tubuh. Oleh karena itu penggunaannya tidak boleh berlebihan, karena dapat berakibat kurang baik bagi kesehatan (Anonim, 2002).

\section{Pengaruh Positif Dan Negatif Makanan Jajanan}

a. Pengaruh Positif Dari Makanan Jajanan

Melalui makanan jajanan anak bisa mengenal beragam makanan yang ada sehingga membantu seorang anak untuk membentuk selera makan yang beragam, sehingga saat dewasa dia dapat menikmati aneka ragam makanan (Khomsan, 2003).

Sedangkan menurut Irianto, P (2007) pada umumnya anak-anak lebih menyukai jajanan diwarung maupun kantin sekolah daripada makanan yang telah tersedia dirumah. Manfaat / keuntungan dari kebiasaan jajan anak yakni :

1. Sebagai memenuhi kebutuhan energi

2. Mengenalkan diversifikasi (keanekaragaman) jenis makanan

3. Meningkatkan gengsi diantara teman-teman

b. Pengaruh Negatif Dari Makanan Jajanan 
Makanan jajanan beresiko terhadap kesehatan karena penanganannya sering tidak higienis yang memungkinkan makanan jajanan terkontaminasi oleh mikroba beracun maupun penggunaan Bahan Tambahan Pangan (BTP) yang tidak diizinkan (Mudjajanto, 2006).

Makanan jajanan mengandung banyak resiko, debu-debu dan lalat yang hinggap pada makanan yang tidak ditutupi dapat menyebabkan penyakit terutama pada sistem pencernaan kita. Belum lagi bila persediaan air terbatas, maka alat-alat yang digunakan seperti sendok, garpu, gelas dan piring tidak dicuci dengan bersih. Hal ini sering membuat orang yang mengkonsumsinya dapat terserang berbagai penyakit seperti disentri, tifus ataupun penyakit perut lainnya (Irianto, K, 2007) .

Menurut Irianto, P (2007) terlalu sering dan menjadikan mengkonsumsi makanan jajanan menjadi kebiasaan akan berakibat negatif, antara lain:

1. Nafsu makan menurun

2. Makanan yang tidak higienis akan menimbulkan berbagai penyakit

3. Salah satu penyebab terjadinya obesitas pada anak

4. Kurang gizi sebab kandungan gizi pada jajanan belum tentu terjamin

5. Pemborosan

6. Permen yang menjadi kesukaan anak-anak bukanlah sumber energi yang baik sebab hanya mengandung karbohidrat. Terlalu sering makan permen dapat menyebabkan gangguan pada kesehatan gigi.

\section{Metode}

Permasalahan siswa-siswi SDN Karangjaya III Kecamatan Pedes Kabupaten Karawang masih kurang dalam pengetahuan dalam memilih jajanan sehat dan aman untuk perkembangan otak yang optimal. Makanan jajanan juga merupakan masalah yang perlu menjadi perhatian masyarakat, karena terdapat beberapa makanan jajanan yang tidak higienis sehingga sangat berisiko terhadap cemaran yang dapat mengganggu kesehatan. Anak sekolah dasar sangat rentan dalam masalah ini karena anak tersebut belum mengerti cara memilih jajanan yang sehat sehingga dapat berakibat buruk pada kesehatannya sendiri Kegiatan ini dikemas dalam bentuk 
penyuluhan. Setelah diberi penyuluhan, selanjutnya mereka dibimbing untuk mengidentifikasi dan membedakan makanan jajanan sehat dan aman untuk anak sekolah dasar.

\section{Langkah-Langkah Kegiatan}

Berikut ini adalah langkah-langkah penyuluhan yang dilakukan:

\section{Tahap Persiapan}

Tahap persiapan yang dilakukan meliputi:

a. Survey

b. Pemantapan dan penentuan lokasi dan sasaran

Penyusunan bahan/ materi penyuluhan, yang meliputi: Makanan jajanan sehat dan Kunci makanan sehat; Bahan/ zat kimia yang berbahaya pada makanan dan identifikasi jajanan dan makanan sehat.

2. Tahap Pelaksanaan Penyuluhan

Tahap pelaksanaan penyuluhan dilakukan persiapan. Dalam tahapan ini dilakukan pertama, penjelasan tentang makanan jajanan sehat, sesi pelatihan ini menitikberatkan pada penjelasan mengenai makanan dan jajanan sehat bagi anak; kedua, sesi penyuluhan yang menitikberatkan pada materi tentang zat/ bahan kimia yang berbahaya pada makanan; ketiga, sesi penyuluhan yang menitikberatkan pemilihan makanan jajanan sehat dan aman dalam mengoptimalkan perkembangan otak anak khususnya anak sekolah dasar.

3. Metode Penyuluhan

Untuk melakukan kegiatan penyuluhan digunakan beberapa metode, yaitu sebagai berikut:

a. Metode Ceramah

Metode ceramah dilaksanakan untuk memberikan penjelasan tentang makanan dan jajanan sehat bagi anak; zat/ bahan kimia yang berbahaya pada makanan; dan pemilihan makanan jajanan sehat dan aman dalam mengoptimalkan perkembangan otak anak khususnya anak sekolah dasar.

b. Metode Diskusi 
Metode diskusi dipilih untuk memberikan keleluasaan siswa dalam bertanya mengenai jajanan sehat dan tidak sehat serta pemilihan makanan jajanan sehat dan aman dalam mengoptimalkan perkembangan otak anak khususnya anak sekolah dasar.

c. Metode Simulasi

Metode simulasi diberikan kepada siswa penyuluhan dalam rangka memberi kesempatan untuk mempraktikan tentang materi pemilihan makanan jajanan sehat dan aman dalam mengoptimalkan perkembangan otak anak khususnya anak sekolah dasar yang ada di sekitar sekolah. Peserta diharuskan memilih jajanan di kantin sekolah.

\section{Hasil dan Pembasahan}

Kegiatan penyuluhan makanan dan jajanan sehat dalam meningkatkan pengetahuan tentang gizi di SDN Karangjaya III Kecamatan Pedes Karawang dilaksanakan pada bulan Agustus 2017. Kegiatan penyuluhan berjalan dengan lancar yang dilakukan oleh 30 siswa. Peserta penyuluhan terlihat antusias dan termotivasi dengan penyuluhan makanan dan jajanan sehat. Ini bisa terlihat dari awal acara penyuluhan sampai akhir acara, semua siswa mengikuti penyuluhan dengan baik dan lancar.

Materi yang diberikan dalam penyuluhan adalah tentang makanan dan jajanan sehat bagi anak; zat/ bahan kimia yang berbahaya pada makanan; dan pemilihan makanan jajanan sehat dan aman dalam mengoptimalkan perkembangan otak anak khususnya anak sekolah dasar.

Pada hari pertama penyuluhan diberikan materi makanan dan jajanan sehat bagi anak serta zat/ bahan kimia yang berbahaya pada makanan. Penyuluhan dilakukan dengan menggunakan media powerpoint dan membawa contoh beberapa makanan dan jajanana sehat. Kemudian dilakukan sesi tanya jawab kepada siswasiswi tentang materi yang telah diberikan. Terlihat antusiasme tinggi pada siswasiswi pada saat penyuluhan.

Hari kedua penyuluhan, siswa-siswa digiring untuk memilih makanan jajanan sehat dan aman di kantin sekolah. Dengan metode simulasi dan praktek 
memilih jajanan di kantin sekolah, siswa-siswi diharapkan bisa membedakan mana jajanan sehat dan jajanan yang tidak sehat.

Berdasarkan hasil kegiatan dapat dilihat hasilnya yaitu siswa-siswa pada saat mempraktikan untuk memilih jajanan sehat di kantin sekolah, terlihat banyak siswa yang sudah paham dan mengetahui mana jajanan sehat yang bisa mereka konsumsi setiap harinya. Ini menunjukkan keberhasilan dalam penyuluhan hampir $80 \%$ berhasil, sebab ini terlihat dari jumlah siswa yang bisa membedakan jajanan sehat dan tidak sehat sekitar 24 siswa dari 30 siswa yang mengikuti penyuluhan.

\section{Simpulan}

Berdasarkan hasil pelaksanaan kegiatan pengabdian pada masyarakat, maka dapat disimpulkan bahwa kegiatan "Penyuluhan makanan dan jajanan sehat dalam meningkatkan pengetahuan tentang gizi di SDN Karangjaya III Kecamatan Pedes Karawang" dapat dilaksanakan dengan baik dan lancar. Penyuluhan dilakukan selama 2 hari dan dihadiri 30 siswa sebagai peserta penyuluhan. Sekitar $80 \%$ yaitu 24 siswa dapat memahami tentang makanan, jajanan sehat dan jajanan tidak sehat.

Penyuluhan dilakukan dengan menggunakan media powerpoint dan membawa contoh beberapa makanan dan jajanana sehat. Kemudian dilakukan sesi tanya jawab kepada siswa-siswi tentang materi yang telah diberikan. Terlihat antusiasme tinggi pada siswa-siswi pada saat penyuluhan. Kemudian siswa-siswa digiring untuk memilih makanan jajanan sehat dan aman di kantin sekolah. Dengan metode simulasi dan praktek memilih jajanan di kantin sekolah, siswa-siswi bisa membedakan mana jajanan sehat dan jajanan yang tidak sehat. 


\section{DAFTAR PUSTAKA}

Anonim. 2011. Anak Sekolah di Indonesia Kurang Gizi. Diakses dari: http://health.kompas.com/blog

2011. Kebiasaan Jajan Serta Kontribusi Energi dan Zat Gizi Makanan Jajan Terhadap Kecukupan Gizi Siswa Sekolah Dasar. Diakses dari: http://fema.ipb.ac.id/index.php/kebiasaan-jajan-sertakontribusi-energi-dan-zat-gizi-makanan-jajanan-terhadapkecukupan-gizi-siswa-sekolah-dasar/

Bramantyo. 2009. Hubungan antara karakteristik, pengetahuan dan sikap siswa dengan perilaku siswa kelas V terhadap bahan tambahan makanan pada jajanan di SDN Mekar Jaya II Depok. Diakses dari: http:/www.library.upnvj.ac.id/pdf/4s1kedokteran/207311100/Bab $\% 201 . p d f$

Bondika. 2011. Faktor yang Berhubungan dengan Pemilihan Makanan Jajanan Pada Anak Sekolah Dasar. Skripsi. Universitas Dipenegoro Semarang. Diakses pada: http://www.eprints.undip.ac.id

Depkes RI. 2005. Pedoman Perbaikan Gizi Anak Sekolah Dasar dan Madrasah Ibtidaiyah. Jakarta: Ditjen Bina Kesehatan Masyarakat Direktorat Gizi Masyarakat

Februhartanty, J \& Iswarawanti.D.N. 2004. Amankah Makanan Jajanan Anak Sekolah di Indonesia? Diakses dari: http://www.gizi.net/cgibin/berita/fullnews.cgi?newsid1097726693.98302

Judarwanto W. 2011. Perilaku makan anak sekolah. Direktorat Bina Gizi Kementerian Kesehatan Republik Indonesia. [Serial online].[diunduh 28 Januari 2013]. Avaliable from: URL: http://gizi.depkes.go.if/makalah/doenload/perilaku\%20anak\%20 sekolah.pdf

2005. Perilaku Makanan Anak Sekolah. Diakses dari: http://gizi.depkes.go.id 
Madarijah, Y. 2010. Perilaku Penjaga Pangan Jajanan Anak Sekolah Terkait Gizi dan Keamanan Pangan di Jakarta dan Sukabumi. Jurnal Gizi dan Pangan 2010. Diakses dari: http://www.journal.ipb.ac.id Muhilal dan Damayanti. 2006. Gizi Seimbang untuk Anak Usia Sekolah Dasar. In:Soekirman, Susana, H., Giarno, M.H \& Lestari Y. EDS. Hidup Sehat: Gizi Seimbang dalam Siklus Kehidupan Manusia. Jakarta:Primamedia Pustaka

Najihah, U.2009. Hubungan antara Pengetahuan Gizi dan Sikap Anak Sekolah Dasar dalam Memilih Makanan Jajanan di Madrasah Ibtidaiyah. Diakses dari: http://etd.eprints.ums.ad.id/5710/2//J300060034.pdf

Notoatmodjo.2003. Pendidikan dan Perilaku Kesehatan. Jakarta:Rineka Cipta.

Ratna. 2004. Hubungan Kontribusi Zat Gizi Makanan Jajanan dengan Status Gizi Pada Siswa SLTP Ibu Kartini Semarang. Abstrak Skripsi. Universitas Diponegoro. Diakses dari: http://www.eprints.undip.ac.id/10634/1/2077.pdf

Saputra.2012. Hubungan Tingkat Pengetahuan dengan Perilaku Siswa Kelas Sekolah Dasar. Semarang: UNNES Journal of Public Health. Diakses dari: http://www.journal.unnes.ac.id

Suci.2009. Gambaran Perilaku Jajan Murid Sekolah Dasar di Jakarta. Psikobuana. Diakses dari: http://www.psikobuana.com Syafitri Y, Syarief H, Baliwati YF. 2009. Kebiasaan jajan siswa Sekolah Dasar. Jurnal Gizi dan Pangan. [serial online] November. Avaliable from: URL: http//journal.ipb.ac.id/index.php/gizipangan/article/viewFile/45 $45 / 3045$ 